\title{
精神科主治医からの情報提供を充実させるために 産業医が依頼文書に記載すべき要素の検討
}

\author{
大河原 眞 ${ }^{1}$, 梶木 繫之 ${ }^{2}$, 楠本 \\ 日野 義之 ${ }^{7}$, 山下 哲史 ${ }^{1}$, 服部 理裕 ${ }^{8}$, 森 晃爾 ${ }^{2}$ \\ ${ }^{1}$ 産業医科大学産業医実務研修センター \\ ${ }^{2}$ 産業医科大学産業生態科学研究所産業保健経営学研究室 \\ ${ }^{3}$ リコー三愛グループ健康推進事業部 \\ ${ }^{4}$ 産業医科大学医学部公衆衛生学教室 \\ ${ }^{5}$ 産業医科大学医学部精神医学教室 \\ ${ }^{6}$ 森本産業医事務所 \\ ${ }^{7}$ ひの労働衛生コンサルタント事務所 \\ 8 一般財団法人西日本産業衛生会
}

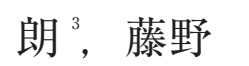

善久 ${ }^{4}$ ， 新開

抄録：目的：産業医-主治医間におけるメンタルヘルス 不調者の就労状況や診療情報の共有方法とその効果に関 する具体的な検証は少ない。本研究では, 精神科主治医 からの診療情報の提供を充実させるため, 産業医から精 神科主治医へ向けた診療情報提供依頼書 (以下 依頼書) に記載すべき内容の検討と, 依頼書の記載内容の違いが 主治医の印象に与える影響の検証を行った。対象と方 法：依頼書に記載が必要な項目及び連携に際して主治医 の抱く懸念を明らかにするため, フォーカスグループ ディスカッション（FGD）を行ったＦGDは 9 名ずつの 異なる精神科医集団を対象として計 2 回実施した. FGD 結果の分析を行い, 依頼書に記載が必要な項目を設定し

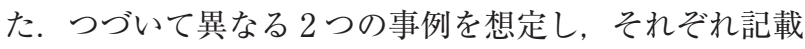
項目, 記載量の異なる 3 パターンの依頼書の雛型の作成 を行ったうえで, 雛型を読んだ精神科医が感じる印象に ついて, 臨床の精神科医に対する質問紙調査を実施し, 得られた回答についてロジスティック回帰分析を行っ た. 結果：FGDの結果から, 依頼書に記載が必要な項目 について, 職場における状況, 確認事項の明確化, 産業 医の立ち位置の表明，主治医が提供した情報の取り扱い

2017 年 3 月 24 日受付；2017 年 9 月 4 日受理

J-STAGE 早期公開日：2017 年 10 月 24 日

連絡先：大河原眞 $=807-8555$ 福岡県北九州市八幡西区医生ヶ 丘 1-1 産業医科大学産業医実務研修センター

Correspondence to: Makoto Okawara, Occupational Health Training Center, University of Occupational and Environmental Health, 1-1 Iseigaoka, Yahatanishi-ku, Kitakyushu, Fukuoka 807-8555, Japan

(e-mail:makotouoeh@med.uoeh-u.ac.jp)
等が抽出された。これらの結果と研究班内での検討をも とに，依頼書に記載が必要な項目を設定した。質問紙調 査の結果は, 設定した記載項目を網羅するにつれ，依頼 書に書かれた情報の十分さや情報提供に対する安心感等 の項目で，好意的な回答の割合が増えた $(\mathrm{p}<.01)$. 一方 で, 読みやすさについては好意的な回答の割合が減った。 考察：産業医と精神科医の連携を阻害する要因として, 主治医が診療情報を提供することで労働者の不利になる 可能性を懸念していること, 産業医が求める診療情報が 明確でないことなどがあることが示唆された，産業医が 依頼書を記載する際に, 文章量に留意しながら記載内容 を充実させ，産業医の立ち位置や提供された情報の使用 方法を含めて記載することで主治医との連携が促進する 可能性があることが明らかとなった．

(産衛誌 2018; 60(1): 1-14)

doi: 10.1539/sangyoeisei.17-009-E

キーワード : Cooperation, Fit for work, Japan, Mental health, Occupational health physicians, Psychiatrists

\section{I. 目 的}

産業保健活動におけるメンタルヘルス不調者への対応 は, 重要な課題となっている. 平成 26 年に公益財団法人 社会生産性本部メンタル・ヘルス研究所が全国の上場企 業を対象に実施した質問紙調査では, 約 3 割の企業にお いて「心の病」が増加傾向にあり, 約 6 割の企業におい て「心の病」が横ばいであると回答している1)。また，平 
成 25 年に厚生労働省が行った労働安全衛生調査 (実態調 查）では, 過去 1 年間にメンタルヘルス不調により連続 1 か月以上休業または退職した労働者が 1 名以上いる事 業所の割合は $10.0 \%$ と上昇傾向にある。そのうち職場復 帰をした労働者がいる事業所の割合は $51.1 \%$ となってい る2).

このような背景を受けて, 産業医による職域でのメン タルヘルス不調者への対応のニーズは年々高まってい る. 産業医が職場復帰や就業支援の判断を適切に行うた めには, 病態や治療状況, 就労に対する主治医の意見な どの情報の入手が不可欠である。メンタルヘルス不調者 の増加および病態の多様化から, 産業医が精神科主治医 (以下 主治医) と連携を行うことの重要性が指摘されて いる. 清水は, 産業医は就業支援に関する明確な基準が ないこと, 一方, 主治医は職場からの情報が得られない と職場の状況の判断材料は労働者からの一方的なものに 止まってしまうことから, 産業医と主治医の連携の必要 性を説いている31. 厚生労働省から出された「改訂 心の 健康問題により休業した労働者の職場復帰支援の手引 き」においても, 主治医による職場復帰可能の判断（第 2 ステップ）において職場で必要とされる業務遂行能力 に関する情報を主治医に提供する, 職場復州の可否の判 断および職場復帰支援プランの作成（第 3 ステップ）に おいて産業医等による主治医からの意見収集を行うな ど, 産業医は事業場内産業保健スタッフの中で主治医と の連携における中心的役割を担う者として位置づけられ ている4).

このように産業医と主治医による連携の重要性が認識 されている一方で, 連携に関する課題についても指摘さ れている。 中野らの報告によると, 約 7 割の産業医が, メンタルヘルス不調において外部精神科医, 心療内科医 との連携に苦慮することがあると回答している5)。これ まで主治医と産業医との連携の重要性を指摘する報告は 多々なされているものの 3,5$)$, どうすれば連携が深まるか については「困った時に気軽に相談できる精神科医を 知っておく」,「研究会などで交流し, 主治医と産業医が 顔見知りとなる」といった一部の産業医が実践できる方 法が提案されているのみであった6,7).

紹介状や診療情報提供書は実際の産業医-主治医間の 情報共有における中心的役割を担うが，情報共有の現状 には課題がある。横山らの調査によると, 主治医と産業 医の連携方法の多くで文書による情報授受を利用してい る8）が, 産業保健の現場では主治医から受け取る診断書 の病名があいまいである等, 十分な情報が得られない状 況が散見されている。島が実施した精神科医等の専門医 を対象とした調査では, 企業に提出する診断書の病名記 載方法において,「実際の病名を正確に反映させる」と回 答した精神科医は $21.2 \%$ に過ぎなかった 9 . 廣は, このよ
うな状況の背景には, 診療情報を職場に提供することで 患者の不利益になる可能性があることや, 産業医がどの ような実務的な役割を担っているかがわからない, 書面 が職場でどのように取り扱われるか不明であるといった 懸念が主治医に存在するためであると述べている10). 友 常らは, 紹介状や診療情報提供書を用いて主治医と産業 医が労働者の情報共有を行う際, 自らが記載する内容と 相手に記載を期待する内容について, 主治医と産業医の 双方に齟䶣があることを明らかにしており, さらに産業 医-主治医間の情報共有の不足を招く原因に, 情報管理の 難しさが影響している可能性について述べている11).

産業医から主治医へ労働者の診療情報の提供を求める 際,「診療情報提供依頼書（以下 依頼書）」を用いて, 文書で主治医へ情報提供を依頼する。主治医は依頼書を 読み, 産業医が求める診療情報に関して情報提供を行う か判断し，「診療情報提供書」を返送する。これまで産業 医から主治医へ提出する紹介状や依頼書に記載すべき項 目や様式の報告は多々なされているものの4,12-16), 依頼 書の内容によって主治医がどのような印象を抱くかにつ いて科学的手法を用いて効果を検証された様式は著者ら の把握する限りでは存在せず, また, 主治医からみて文 書による産業医との連携にどのような懸念事項がある か, については明らかとなっていない。

本研究は, メンタルヘルス不調者の就業支援を行う産 業医が, 主治医との良好な連携を行う際に依頼書に記載 すべき内容を明らかにするため, 記載内容及び情報量が 異なる依頼書を複数作成し, 読みやすさ, 依頼内容の明 確さ, 情報提供に対する安心感などの違いに関する評価 を実施した。

\section{II. 方 法}

本研究は,（1）充分な診療情報の提供を受けるため, 依頼書に記載が必要な項目の抽出のために実施した精神 科医を対象としたフォーカスグループディスカッショ ン,（2）充分な診療情報の提供を受けるために必要な項 目を記載した診療情報提供依頼書の雛型 (以下 㱀型)の 作成，（3）必要と設定した項目の網羅性と精神科医が抱 く印象の関連を検証するための質問紙調査の 3 つからな る. 以下それぞれについて，方法を示す.

\section{精神科医を対象としたフォーカスグループディスカッ ション（FGD）}

研究班会議において，精神科医としての経験年数など を考慮し調査対象者を選定した．対象はそれぞれ 9 名ず つの，異なる $2 つ の$ 精神科医の集団とした.

一方の集団は大学病院, 総合病院, 単科精神科病院, 精神科クリニックなどに勤務する一般精神科医の集団 
で, 9 名中 5 名は産業医資格を有し, 3 名は企業において 産業医実務経験がある。もう一方の集団は，大学病院に 勤務する一定の産業医学教育を受けた精神科医の集団 で, 全員が産業医資格を有し, 内 5 名は企業において産 業医実務経験がある。一定の産業医学教育を受けた集団 の 9 名中 8 名が医学部在学中に 240 時間程度の系統的な 産業医学教育を受けた，もしくは産業医学基本講座にお いて 180 時間程度の系統的な産業医学教育を受けた者で ある. 9 名中 1 名は, 日本医師会が実施する産業医学基礎 研修に扔いて 50 時間以上の研修を修了した者である. 本 論文の巻末に，それぞれの FGD の参加者の属性を添付 する (添付資料 1).

いずれの FGD においても共著者のうち 1 名（SK）が ファシリテーターを担当し,「充分な診療情報の提供を受 けるために必要な依頼書の記載項目」,「産業医との連携 に扔ける主治医側の懸念事項」,「連携に際して産業医に 明確にしてもらいたい点」を主題として2つのグループ でそれぞれ 1 回ずつFGD を実施した. 1 回の FGD に費 やした時間は, 一般精神科医集団で約 90 分, 一定の産業 医学教育を受けた精神科医集団で約 60 分であった. 新規 の意見が出なくなったことを持って当該グループにおけ る意見の抽出に充分な時間を費やしたと判断し，FGD を終了した。

一定の産業医学教育を受けた集団における FGD で は, 一般精神科医集団に扔ける FGD で挙げられた意見 を口頭で例示した上で, 主題についての追加意見や修正 を求めた。

FGD 内では, 主題に沿った議論となるよう, 適宜ファ シリテーターが議論の方向性に言及して関与した.

デー夕の分析は共著者の内 1 名 $(\mathrm{AK})$ が行った. 実施 した FGD のスクリプトをもとに, FGDの主題に沿った 自由回答を $\mathrm{KJ}$ 法を参考に類似性に従って分類し, 1 例以 上の回答がある分類項目について全てネーミングし, 記 録単位群とした，その後, 研究班内で分類と解釈の妥当 性について検討した。

\section{雛型の作成}

FGD の結果をもとに, 研究班での会議及び複数の専門 産業医（日本産業衛生学会産業衛生指導医, 労衝衛生コ ンサルタント資格保持者）の意見聴取を経て，産業医が 主治医へ診療情報の共有を依頼するために必要な記載項 目について設定した，その過程で, FGDでは提示されな かったが記載が必要であると考えられる項目を, 研究班 内の検討により追加した.

続いて, 個人属性及び病態の異なる $2 つ の$ 事例を想定 し, それぞれについて, 記載量・記載内容の異なる 3 パ ターンの依頼書の雛型を作成した。

事例及びパターンは研究班内の検討により決定した.
$2 つ の$ 事例において想定する疾患は, うつ病 (事例 I), 統合失調症（事例 II）とした.

事例 I は事例に遭遇する頻度が高いこと, 事例 II は診 療情報の企業内での取り扱い方によっては労働者が不利 な状況に置かれる可能性があり，かつ各年代において一 定の罹患率があることを理由に選定した.

3 つのパターンについて, パターン 1 は 150 文字程度 で情報量が少なく一方的に主治医からの情報提供を求め るもの(氏名, 年齢, (1) 確認項目について記載), パター ン 2 は 750 文字程度で中程度の情報量で, パターン 1 に 加え産業医からの情報提供を充実させる記載を追加する 目的で, 情報提供を求める理由について記載したもの(パ ターン 1 に加え, (2) 確認したい理由について記載), パ ターン 3 は 1000 字程度で充分な情報量で, パターン 2 に加え主治医の懸念を低減する対策を追加する目的で, 産業医の立ち位置や情報の取り扱い方について記載した もの（パターン 2 に加え，（3）産業医の立ち位置の表明 と（4）主治医が提供した情報の取り扱いについて記載) とした.

本論文の巻末に, 作成した雛型の 2 つの事例について, それぞれ 3 つのパターンの記載例を添付する（添付資料 2).

\section{精神科医への質問紙調查}

作成した雛型を用い, 記載が必要と設定した項目の網 羅性の違いによって, 依頼書を読んだ精神科医の印象に どのような違いが生じるかを検証するため, 臨床医の精 神科医・心療内科医への質問紙調查を実施した.

平成 28 年 11 月 8 日 22 日の間に, 福岡県精神保健福 祉協会及び福岡県精神神経科診療所協会に登録している 95 名の精神科医 - 心療内科医に対して, 無記名式の質問 紙調查を実施した。

事例ごとに各パターンを示した上で, 以下 6 項目の質 問について，5段階のリッカート尺度(例 読みやすさ： 1. 非常に読みにくい〜 5. 非常に読みやすい) で評価を 依頼した. (1)読みやすさ…雛型を読んだ精神科医にとっ て, 雛型の文章構成や文章量において読む上での負担が ないか. (2) 情報の十分さ…雛型を読んだ精神科医にとっ て, 企業または産業医と連携をする上で知りたい情報が 十分に記載されているか.（3）確認事項の明確さ…雛型 を読んだ精神科医にとって, 産業医が求める確認事項が 明確であるか．（4）産業医の立ち位置の明確さ…雛型を 読んだ精神科医にとって, 依頼書を書いた産業医が企業 内でどのような立ち位置で労働者の支援を行っているか が明確であるか（5）情報提供に対する安心感...雛型を 読んだ精神科医にとって，当該依頼書を提出した企業ま たは産業医に診療情報を提供することに対して安心でき るか.（6）返書の書きやすさ…雛型を読んだ精神科医に 
とって, 確認事項の明確さや情報提供に対する安心感等 を含め返書を書きやすい依頼書であったか. 各評価項目 における 4 点以上(例：読みやすい, 非常に読みやすい) を「好意的な回答」と定義した.

まず, 2 つの事例を比較して, 各評価項目について, 好 意的な回答に該当するオッズ比をロジスティック回帰分 析を用いて推定した。すなわち, 各評価項目について, 好意的な回答に該当するかを従属変数として, 独立変数 として，事例の種類を用いた.

次に, 2 つ事例の間において, 好意的な回答の割合に

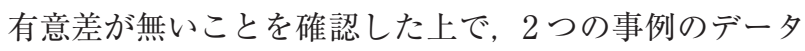
を統合した。

統合したデータを用い, 依頼書の 3 つのパターンを比 較して, 各評価項目について，好意的な回答に該当する オッズ比をロジスティック回帰分析を用いて推定した. すなわち, 各評価項目について, 好意的な回答に該当す るかを従属変数として, 独立変数として, 診療情報提供 依頼書パターンを用いた。解析にはStata Ver.14.0 (株式 会社 ライトストーン, 東京) を用い, 有意確率は 0.05 以下とした。

\section{III. 結 果}

精神科医を対象としたフォーカスグループディスカッ ション（FGD）

主題に沿った意見として 50 件の有効回答が得られ, 充 分な診療情報の提供を受けるために必要な項目として, 5 つの記録単位群に分類された。

以下に FGDの分析結果の要約, 各記録単位群の記録 単位数, および抽出された意見のうち類型化に役立った 例を示す.

（1）職場内での本人の様子や職場の制度など，職場に おける状況について

職場からの評価や周囲からみた本人の様子, 人間関係 などの情報を提供することで診療上有益な情報を提供し 得ることが示唆された。 また, 職場の制度や取り得る配 慮の範囲に関する情報を提供することで, 職場の実情に 則した意見や診療情報が提供される可能性が示唆された (記録単位数 19 件).

「会社として本人がどう見られていたのかわからない ので，休職前の状沉などの情報をもらえるとありがた い」(精神科経験年数 10-20 年 産業医経験あり)

「職場内の人間関係や評価などを知りたい」(精神科経 験年数 20-30 年 産業医経験無し)

「職場によってどれぐらい配慮できるのかが違うため, 職場がどの程度まで配慮できるのかの情報があったほう が, 主治医としても助かる」(精神科経験年数 10-20 年 産業医経験あり)
「異動させるとして, 部署の選択肢や具体的な業務内容 などが分かれば意見しやすい」(精神科経験年数 5-10 年 産業医経験無し)

「(復職における) リハビリの状況などの情報があれば 連携しようと思う」(精神科経験年数 20-30 年 産業医経 験無し)

（2）産業医の見立て

職場環境を把握している企業内専門家として, 事例性 を踏まえた産業医からの意見の記載の必要性が示唆され た (記録単位数 1 件).

「産業医が思うところや, 職場でどう病状を考えている のか, 産業医からの考えを教えてほしい」(精神科経験年 数 20-30 年 産業医経験無し)

（3）確認事項の明確化

現状では産業医が主治医へ情報提供を求める事項が不 明確であり, 確認事項をより明確に記載することを求め る意見が複数みられた．産業医や企業が求める情報につ いて明確に記載することの必要性が示唆された（記録単 位数 9 件).

「産業医から確認したい事項について細かく聞かれた ほうが答えやすい」(精神科経験年数 10-20 年＼cjkstart産業医経 験無し)

「どういう情報を求められているのかが分からないた め, どこまで情報を伝えていいか分からない」(精神科経 験年数 10-20 年 産業医経験あり)

「診断書上はうつ病だが背景には発達障害がある場合 などもある。どこまで情報が欲しいのかを明確にしてほ しい」(精神科経験年数 20-30 年 産業医経験無し)

「目的と内容がはっきりしていると答えやすい」(精神 科経験年数 20-30 年 産業医経験無し)

(4) 産業医の立ち位置の表明

産業医が労働者と企業の双方に中立的な立場なのか, もしくは企業の利益や意向のみを優先する立場なのかが 書面上では不明確であり，懸念を持つ意見が複数みられ た. 産業医の立場や考えを明確にし, 労働者にとって有 効な職場環境を提供する立場にあると表明することの必 要性が示唆された（記録単位数 13 件).

「産業医の顔が分からないと, 企業側の人間ではないか 等を懸念する」(精神科経験年数 5-10 年 産業医経験無 L)

「どれぐらいの職員と関わりがあって, 産業医としてこ こまで関与できるという情報が必要」(精神科経験年数 10-20 年 産業医経験あり)

「企業内の立場である産業医から聞かれてどこまで回 答して大丈夫かとは考える。不利益にならないかが心 配」(精神科経験年数 20-30 年 産業医経験無し)

「完全に企業の立場に立って積極的にリストラに加担 する産業医は，少ないがいないわけではない。そこが怖 
表 1. 回答者の属性 $(\mathrm{n}=26)$

\begin{tabular}{|c|c|c|}
\hline 項目 & $\begin{array}{r}\text { 人数 } \\
\text { 中央值 }\end{array}$ & $\begin{array}{l}\text { （\%）または } \\
\text { (四分位範囲) }\end{array}$ \\
\hline 医師経験年数 & 31 & $(24.5-35.3)$ \\
\hline \multicolumn{3}{|l|}{ 性別（\%） } \\
\hline 男性 & 22 & (85) \\
\hline \multicolumn{3}{|l|}{ 年齢（\%) } \\
\hline 40 代 & 5 & (19) \\
\hline 50 代 & 10 & (39) \\
\hline 60 代 & 11 & $(42)$ \\
\hline 精神保健指定医の有資格者 & 24 & $(92)$ \\
\hline 精神科専門医の有資格者 & 19 & (73) \\
\hline 産業医経験の有る者 & 10 & (39) \\
\hline 主治医としての産業医との連携の経験のある者 & 25 & (96) \\
\hline 産業医との連携で困った経験のある者 & 16 & $(62)$ \\
\hline
\end{tabular}

い」(精神科経験年数 20-30 年 産業医経験無し)

「我々は基本的に患者の立場に立つ. 産業医が職場側で あれば，対立することになる，産業医の立場が分からな い」(精神科経験年数 20-30 年 産業医経験無し)

（5）主治医が提供した情報の取り扱い

具体的な病名や障害名を職場に提供することで, 解雇, 降格, 職場内での偏見や差別などの労働者の不利益にな る事象が生じることを㲘念する意見が複数みられた。ま た，職場内での情報管理体制が主治医にとって不明確で あり，提供した情報が社内でどのように扱われるかが把 握できないことも，これらの主治医の懸念を悪化させて いることが示唆された（記録単位数 8 件).

「こちらの説明が職場でどう捉えられるのか．本人に とって不利に捉えられるのではないか」(精神科経験年 数 10-20 年 産業医経験あり)

「若年性認知症の患者の適正配置に関する意見を求め られた際に，具体的な病名を伝えると解雇になるのでは ないかと悩んだ経験がある」(精神科経験年数 5-10 年 産業医経験無し)

「ハラスメントの問題を聴取した際, 主治医から産業医 に伝えた場合，産業医がその情報をどう扱うのかが不明 なため懸念がある」(精神科経験年数 20-30 年 産業医経 験無し)

依頼書に記載が必要な項目について, FGD で記載が必 要と提示された項目に加え,「面接で聴取した内容」,「主 治医の治療方針の確認」を追加し，以下のように設定し た（0）挨拶文，（1）確認項目，（2）確認したい理由, （2-1）職場に打ける状況，（2-2）面接で聴取した内容, （2-3）主治医の治療方針の確認，（2-4）産業医の見立て,

(2-5) 確認事項の明確化, （3）産業医の立ち位置の表明,

（4）主治医が提供した情報の取り扱い.

\section{精神科医への質問紙調査}

回収率は $28 \%$ (27 件) であった，欠損のあった 1 件を 除外し, 26 件を解析対象とした.

（1）回答者の属性

精神保健指定医有資格者は 24 名 (92\%) で，精神科専 門医有資格者は 19 名（73\%）であった，産業医として勤 務した経験のある者は 10 名 (39\%) であった，主治医と しての産業医との連携の経験のある者は 25 名(96\%)で, 産業医との連携で困った経験のある者は 16 名 $(62 \%)$ で あった（表 1)。

（2）各評価項目に扔ける事例間の差の分析

事例 I と事例 II の間において, 各評価項目における好 意的な回答を選択した者の割合は, いずれの項目におい ても有意な差は認めなかった。

（3）各評価項目におけるパターン間の差の分析

$2 つ の$ 事例におけるデー夕を統合して 52 件を分析対 象とした.

「読みやすさ」以外の評価項目における好意的な回答の 割合は, パターン 1 と比較してパターン 2,3 で有意に増 加した。「読みやすさ」の評価項目に扔ける好意的な回答 の割合は, パターン 1 と比較してパターン 3 で有意に減 少した．各評価項目におけるパターン 1 に対するパター ン $2 ， 3$ のオッズ比掠よび $95 \%$ 信頼区間を示す（表 2).

\section{IV. 考 察}

本研究では, 産業医学に関する教育・研修歴や実務経 験および所属医療機関について多様な背景を持つ精神科 医を対象にした FGD を行い，産業医と主治医の連携の 際に依頼書に記載が必要な項目について探索し分類する ことを試みた。 その過程で, 主治医が抱く懸念として, 診療情報の提供により労働者が不利益を受ける可能性が 
表 2. 各評価項目における好意的な回答及びパターン 1 に対するオッズ比 $(n=52)$

\begin{tabular}{|c|c|c|c|c|c|}
\hline 項目 & $\begin{array}{l}\text { 好意的な回答 } \\
\text { の数 }(\%)^{\mathrm{d})}\end{array}$ & オッズ比 & \multicolumn{2}{|c|}{ 95\% 信頼区間 } & $\mathrm{p}$ 值 \\
\hline \multicolumn{6}{|l|}{ 読みやすさ } \\
\hline パターン 1a) & $40(77 \%)$ & reference & & & \\
\hline パターン $2^{\mathrm{b})}$ & $43(83 \%)$ & 1.4 & 0.6 & 3.8 & 0.47 \\
\hline パターン 3c) & $29(56 \%)$ & 0.4 & 0.2 & 0.9 & 0.02 \\
\hline \multicolumn{6}{|l|}{ 情報の十分さ } \\
\hline パターン 1 & $4(8 \%)$ & reference & & & \\
\hline パターン 2 & $29(56 \%)$ & 15.1 & 4.8 & 48.2 & $<0.01$ \\
\hline パターン 3 & $50(96 \%)$ & 300.0 & 52.5 & 1714.3 & $<0.01$ \\
\hline \multicolumn{6}{|l|}{ 確認事項の明確さ } \\
\hline パターン 1 & $7(13 \%)$ & reference & & & \\
\hline パターン 2 & $30(58 \%)$ & 8.8 & 3.3 & 23.1 & $<0.01$ \\
\hline パターン 3 & $48(92 \%)$ & 77.1 & 21.2 & 281.4 & $<0.01$ \\
\hline \multicolumn{6}{|c|}{ 産業医の立ち位置の明確さ } \\
\hline パターン 1 & $3(6 \%)$ & reference & & & \\
\hline パターン 2 & $22(42 \%)$ & 12.0 & 3.3 & 43.5 & $<0.01$ \\
\hline パターン 3 & $44(84 \%)$ & 89.8 & 22.4 & 359.9 & $<0.01$ \\
\hline \multicolumn{6}{|c|}{ 情報提供に対する安心感 } \\
\hline パターン 1 & $4(8 \%)$ & reference & & & \\
\hline パターン 2 & $21(41 \%)$ & 8.1 & 2.6 & 26.0 & $<0.01$ \\
\hline パターン 3 & $45(86 \%)$ & 77.1 & 21.2 & 281.4 & $<0.01$ \\
\hline \multicolumn{6}{|l|}{ 返書の書きやすさ } \\
\hline パターン 1 & $2(4 \%)$ & reference & & & \\
\hline パターン 2 & $22(43 \%)$ & 18.3 & 4.0 & 83.5 & $<0.01$ \\
\hline パターン 3 & $44(84 \%)$ & 138.0 & 27.7 & 682.1 & $<0.01$ \\
\hline
\end{tabular}

a) (1) 確認項目について記載

b)（1）に加え，(2）確認したい理由（職場における状況, 面接で聴取した内容, 主治医の治 療方針の確認, 産業医の見立て, 確認事項の明確化）について記載

c)（1），(2) に加え，（3）産業医の立ち位置の表明，（4）主治医が提供した情報の取り扱い について記載

d) 各評価項目における好意的な回答（例：読みやすい，非常に読みやすい）を選択した者の 割合

あること，産業医の立場や姿勢が不明確であること，主 治医からの要望として，産業医や企業が共有したい情報 の明確化, 提供した診療情報の取り扱い方法の明確化, があることを明らかにした。また，上記の結果をもとに 依頼書の雛型を作成し，精神科医への質問紙調査により 記載が必要と設定した項目の網羅性と主治医の印象の関 連性を示した。

\section{産業医と主治医の立場の違い}

産業医と主治医は，職能や特性が大きく異なる，産業 医は，職務上は診断・治療の中心的機能は有さない場合 が多く, 治療や疾病性の把握における中心的役割は主治 医に委ねることとなる。一方で主治医は，就業状況，作 業環境，職場内の人間関係などを実際に確認するため企 業に出向くということは現実的には困難で，問診で本人 や家族から聴取する以外には，産業医との情報共有が重 要な情報資源となる ${ }^{3)}$. 産業医と主治医は, お互いが持っ ている情報を共有し連携することで，それぞれの活動の 効果を高めることができると考えられており7), 横山ら
の調査においても，連携による成功事例のうち，約 9 割 で両立できる業務内容調整の実現等の就業面での効果, 約 6 割で産業医からの情報の診断・治療への活用等の治 療面での効果を認めている17).

一方で，産業医と主治医の充分な連携を阻害する要因 として，産業医と主治医の立場の相違がある。産業医は 企業内の専門家として中立的な立場で事例性の観点から 意見を述べる. 企業が取り得る対応には限界があるため, 労働者の希望と一致しない場合があり，必ずしも労働者 のすべての希望が意見に反映されるわけではない.一方， 主治医は患者個人との診療契約に基づいて治療を行って おり，医師患者間の信頼関係の構築の観点からも，本人 の希望や利益を優先する傾向にある。これらの産業医と 主治医の立場の相違は, 夏目の論文に詳しい7).このよう な立場の相違が背景にあることを考えれば, 主治医が信 頼関係を構築していない産業医への詳細な情報提供を躊 躇することは妥当な判断であるといえる，産業医と主治 医の連携が成功するためには，連携に対する「主治医の 理解の強さ」が大きく影響しており17), 産業医と主治医 
の立場の違いを踏まえた上で，いかに主治医の理解を得 るかが, 連携の成否を決める重要な要素となると考えら れる。

\section{依頼書に記載が必要な要素}

FGDの分析結果からは主治医としては産業医との連 携を望んでいる反面, 産業医の立ち位置や考えが確認で きないことから，提供した情報の取り扱い方法によって は労働者の不利益になる可能性を懸念していることが示 唆された.これは先行研究10,11,16)の考えを支持するもの であるが，これまで開発された様式例には産業医の立ち 位置を依頼書内に明確に記載するよう指定したものは無 く, 実際の依頼書においても産業医の立ち位置について 記載している例は多くないと推測される。本研究の結果 から，中立的な立場で本人にとって有効な職場環境を提 供する産業医であるという立場を明確に表明し，主治医 の信頼を得ることで, 充分な診療情報の提供を受けるこ とが出来る可能性があることが明らかとなった．また, 情報の取り扱い方法や社内での使用目的についても詳細 に記載し, 情報提供に際し本人の同意があることを示す ことで, 主治医が安心して情報提供を行えると考えられ る.

また, 確認したい事項が明確でないことも, 主治医か らの情報提供を阻害する要因となることが示唆された. これについても同様に，主治医が把握している情報のう ち何が必要なのかを明確に伝えることで, 主治医からの 情報提供の促進に繋がると考えられる.

䛦療情報を求める理由を詳細に記載することが必要で あるという分析結果は, 友常らの質問紙調査11)の結果と 一致していた。職場で問題となったエピソードや職場で 可能な対応等は, 本人からの問診だけでは主治医が把握 しづらい情報である。必要な理由を記載する過程で, こ れらの情報を提供することとなり, 結果的に診療の補助 となるという効果もある. 職場での状況を含めて, 確認 事項や確認したい理由を記載することが重要と考えられ る.

本研究の FGD では抽出されなかったが, 研究班内の 検討により記載すべき項目として追加した項目は，いず れも先行する多くの様式例や文献に記載が针められてい る内容と類似していた12,13).

\section{依頼書の記載項目と主治医の印象の関連性}

これまで，依頼書の記載項目によって，主治医の印象 にどのような変化が生じるかを具体的に検証した研究は 無い. 本研究では, 事例や病態を詳細に想定し, 実際に 使用する依頼書に類似した雛型を作成した。精神科医へ の質問紙調査では, この雛型を用いて依頼書の記載項目 と主治医の印象との関連を推定しており, 依頼書に記載
が必要な項目について研究的手法を用いて探索した点が 本研究における新規性のひとつであると考える.

質問紙調査の結果はFGDの分析結果から得られた考 察を支持するものであった。

依頼書の記載項目が増えると, 主治医が感じる情報の 十分さ, 確認事項の明確さ, 産業医の立ち位置の明確さ, 情報提供に対する安心感, 返書の書きやすさの項目にお ける好意的な回答は有意に増加した。これらは，依頼書 に記載が必要であると設定した項目の妥当性を示したも のと考えられる。

パターン 2 はパターン 1 と比較して，(2) 確認したい 理由, が追加されている. これは, 産業医から主治医へ の情報提供が充実し, 確認事項が明確になることで, 返 書の内容も充実するという関係性を明らかにしたものと 考える.

一方で, パターン 2 では主治医の懸念を低減する記載 は追加されていないにも関わらず, 産業医の立ち位置の 明確さや情報提供に対する安心感の項目における好意的 な回答にも有意に増加がみられた。これらは産業医資格 の有無や産業医経験の有無について調整した場合でも同 様であった。

職場における状況等を詳細に記載すること自体が, 労 働者の支援に対して誠実に取り組んでいる産業医である と受け取られ，産業医の立ち位置や情報提供の安心感に おいても好意的に解釈されたのではないかと推測され る.

パターン 3 はパターン 2 と比較して,（3）産業医の立 ち位置の表明，（4）主治医が提供した情報の取り扱い, が追加されている.これらはFGD及び先行研 究10,11,16) で明らかになっている主治医にとっての懸念 事項である, 診療情報の提供によって労働者に不利益が 生じる可能性があることについての対応策となり得る。

これらの 2 項目について記載し, 主治医の信頼を得る工 夫をすることで，返書の内容をより充実させることが可 能になると考える.

一方で, パターン 3 とパターン 1 の比較において, 読 みやすさの項目では好意的な回答の割合に有意な減少が みられた. 文章量が 150 字程度から 1000 字程度に増加し たことに伴うものと考えられる. また，比較的長文にも 関わらず，文章が構造化されていない点も，読みやすさ が低下する要因のひとつであった可能性がある。これら より，今後依頼書の内容を充実させる産業医が増えるに 従って主治医の負担が増える可能性が示唆された。対策 として, 必要な項目は記載しつつ, 可能な限り文章が冗 長にならないようにする, 見出しを付けて文章を構造化 する等の工夫が考えられる。

$2 つ の$ 事例の間における好意的な回答の割合には, い ずれの項目においても有意な差は認めなかった。この結 
果から, 少なくとも 2 つ異なる病態・事例において, 本研究で記載が必要と設定した項目が主治医の印象に同 様の影響を与えた可能性が示唆された。すすなわ，本研 究で設定した項目を記載することで, 異なる病態や事例 においても主治医との情報共有に好影響を与える可能性 を示した。

\section{本研究の限界}

本研究では, 連携に際して主治医が抱く懸念や依頼書 に記載が必要な項目について新たな知見を得るため FGD を用いて探索的に検討を行ったＦGDの対象は計 18 名の精神科医に限られ，開業医の参加者が少ないた め, FGD の結果のみをもって設定した項目を一般化する ことが困難であることは FGD に扔ける方法論的限界で ある。 そのため記載が必要であると設定した項目以外に も主治医との連携を促進する項目が存在する可能性があ る. 本研究では専門産業医の意見や先行研究を踏まえて 項目の追加を行ったことで最低限必要と考えられる項目 については網羅し，さらに開業医を中心とした質問紙調 查を組み合わせることによって, 設定した項目の妥当性 を確認した。

質問紙調查において, パターン 3 に追加された (3) 産 業医の立ち位置の表明，（4）主治医が提供した情報の取 り扱い，の内どちらか一方の項目が主治医の印象に影響 したのか, あるいは両方の項目が主治医の印象に影響し たのかは, 本研究では判断が出来ない.すなわち, これ ら 2 項目を記載することの必要性は FGD の抽出結果か ら明らかになったが，それぞれの項目単体の記載によっ て主治医の印象に好影響を与えるとは断定出来ない.

質問紙調查に用いた事例は 2 種類のみであり，同一の 評価者が繰り返し評価を行っている，そのため本研究の 結果のみをもって，記載が必要であると設定した項目が 全てのメンタルヘルス不調に係る事例に有用であると結 論付けることは困難である.

質問紙調查に用いた依頼書のパターンI-3に扔いて, 依頼書の内容や, 主治医からの診療情報の取得に関する 本人同意を文章中に表現したが，より主治医に安心感を 持ってもらうため, 実際の連携の際には, 本人署名の欄 を作成するなどし, 本人同意をより明確に表現すること が必要と考えられる.

また質問紙調查の回収率は $28 \%$ であり，回答した精神 科医は元々連携に関心の高い集団であった可能性があ る. 本研究では産業医との連携を行う精神科医が文書に よるやりとりの際に抱く懸念とその対応策を検討した が，そもそも連携に関心の低い精神科医と連携を行うた めには依頼書の様式の工夫のみでは不十分であり, 返書 様式の工夫や文書作成に対する金銭的対応等の検討も重 要な課題である.

\section{今後の展開}

本研究の結果を踏まえ, メンタルヘルス不調者の就業 支援に扔ける主治医と産業医の連携の促進のため, 依頼 書を記載する際の項目や記載方法について定めた, 「診療 情報提供依頼書作成マニュアル」を製作し, 産業医向け に提供していく，今後，製作したマニュアルを使用した 産業医から, 使用感や主治医からの情報提供内容の変化 に関する意見聴取や質問紙調査を行い，妥当性の更なる 検証を行う予定である。

謝辞：FGD 及び質問紙調查にご協力いただいた精神科医の 先生方に深謝いたします. 本研究は産業医科大学 平成 27 年度抒よび平成 28 年度産業医学・産業保健重点研究助成金 による助成を得て行われました。

本研究における開示すべき利益相反はない.

\section{文 献}

1）公益財団法人 日本生産性本部 メンタル・ヘルス研究 所. 第 7 回『メンタルヘルスの取り組み』に関する企業ア ンケート調查結果. [Online]. Available from: URL: http:// activity.jpc-net.jp/detail/mhr/activity001425.html

2) 厚生労働省 平成 25 年労働安全衛生調查

3）清水英佑. 産業医と精神科医との連携によるメンタルー ルス対策について。産業精神保健 2009; 17(4): 222-226.

4）厚生労働省 中央労働災害防止協会 改訂：心の健康問 題により休業した労働者の職場復帰支援の手引き 2009

5）中野英樹, 新開隆弘, 中村 純. 職場のメンタルヘルスの 現状一産業医㧍よび精神科医へのアンケート調査か ら一. 産業精神保健２007; 15(3): 156-164.

6）植木啓文. 精神科主治医と産業医・衛生担当者との連携 を目指して。臨床精神医学 2013; 42(10): 1259-1264.

7）夏目 誠. 精神科医は産業医や保健師とどのように連携 することができるか，精神科治療学 2008; 23(11): 13071312.

8）横山和仁. 主治医との連携に対する意識と連携実態に影 響する因子の検討. 労災疾病臨床研究事業費補助金 主 治医と产業医の連携に関する有効な手法の提案に関する 研究. 横山和仁. 平成 27 年度総括. 分担研究報告書

9）厚生労働科学研究費補助金 労働安全衛生総合研究事業 うつ病を中心としたこころの健康障害をもつ労働者の職 場復帰扔よび職場適応支援方策に関する研究. 島 悟. 平成 16 年度総括研究報告書

10）廣 尚典. 産業精神保健における精神科医と産業医の連 携. 精神神経学雑誌 2008; 110(10): 1103-1108.

11）友常祐介. 心の健康問題を抱えた労働者への対応におけ る産業医一精神科医間の意識差に関する研究. 体力・栄 養・免疫学雑誌 2013;23(2): 87-94. 
添付資料 1. フォーカスグループディスカッション参加者の属性

\begin{tabular}{|c|c|c|c|c|}
\hline 精神科経験年数 (年) & 産業医資格 & 産業医実務経験 & & その他 \\
\hline \multicolumn{5}{|c|}{ 1. 一般精神科医のグループ $(\mathrm{n}=9)$} \\
\hline 30 年以上 & $\bigcirc$ & 0 & 精神保健指定医 & 大学病院勤務 \\
\hline $20-30$ & 0 & & 精神保健指定医 & 単科精神科病院勤務 \\
\hline $20-30$ & & & 精神保健指定医 & 単科精神科病院勤務 \\
\hline $10-20$ & $\bigcirc$ & 0 & 精神保健指定医 & 大学病院勤務 \\
\hline $10-20$ & 0 & 0 & 精神保健指定医 & 精神科開業医 \\
\hline $10-20$ & & & 精神保健指定医 & 大学病院勤務 \\
\hline $5-10$ & & & & 大学病院勤務 \\
\hline $5-10$ & & & & 大学病院勤務 \\
\hline $5-10$ & $\bigcirc$ & & & 総合病院勤務 \\
\hline \multicolumn{5}{|c|}{ 2. 一定の産業医学教育を受けた精神科医のグループ（n=9） } \\
\hline 30 年以上 & $\bigcirc$ & ○ & 精神保健指定医 & （2）大学病院勤務 \\
\hline $20-30$ & $\bigcirc$ & $\bigcirc$ & 精神保健指定医 & （1），(2）大学病院勤務 \\
\hline $5-10$ & 0 & 0 & 精神保健指定医 & （1）大学病院勤務 \\
\hline $5-10$ & $\bigcirc$ & & 精神保健指定医 & （1）大学病院勤務 \\
\hline $5-10$ & $\bigcirc$ & & 精神保健指定医 & （1）大学病院勤務 \\
\hline $5-10$ & 0 & & & 大学病院勤務 \\
\hline $5-10$ & $\bigcirc$ & $\bigcirc$ & 精神保健指定医 & （2）大学病院勤務 \\
\hline $5-10$ & $\bigcirc$ & & 精神保健指定医 & （1），(2）大学病院勤務 \\
\hline $5-10$ & 0 & 0 & & （1）大学病院勤務 \\
\hline
\end{tabular}

(1) 医学部在学中に 240 時間程度の系統的な産業医学教育を受けた者

（2）産業医学基本講座において 180 時間程度の系統的な産業医学教育を受けた者

12）笹原信一朗，吉野 聡，友常祐介，ほか。産業医-精神科 医の円滑な連携を目指した実践的研究. [Online]. Available from: URL: http://www.ibarakis.johas.go.jp/publicit $\mathrm{y} / \mathrm{research} /$ sasahara23.html

13）中村 純. 産業医と精神科医との連携による職域のメン タルヘルスケアー手法と実際．産業医学レビュー 2005; 18(3): 139-152.

14）堤 明純. 職域メンタルヘルス不調の予防と早期介入・ 支援のための産業医向け教育プログラムの開発．厚生労 働科学研究費補助金 労働安全衛生総合研究事業 労働 者のメンタルヘルス不調の予防と早期支援・介入のあり 方に関する研究. 横山和仁. 平成 22 年度総括・分担研究 報告書
15）原谷隆史, 大塚泰正, 深澤健二, 中田光紀. 産業医 - 健康 管理担当者のための地域精神科医・医療機関との連携マ ニュアルの作成. 厚生労働科学研究費補助金 労働安全 衛生総合研究事業 労働者のメンタルヘルス対策におけ る地域保健・医療との連携のあり方に関する研究．横山 和仁. 平成 18 年度総括・分担研究報告書

16）武藤 剛, 横山和仁, 北村文彦, 福田 洋. 嘱託産業医と 主治医の連携。保健の科学 2015; 57(9): 595-602.

17）横山和仁. 産業医と主治医の連携の効果と, 非連携の不利 益, そして連携の成否に影響する要因一（産業医側連携事 例調查の分析から). 労災疾病臨床研究事業費補助金 主 治医と産業医の連携に関する有効な手法の提案に関する 研究. 横山和仁. 平成 27 年度総括. 分担研究報告書 
添付資料 2 .

\section{診療情報提供依頼書 \\ パターン I -1}

○○ンタルクリニック

$\bigcirc \bigcirc \bigcirc \bigcirc$ 院長先生 御机下

(株) $\bigcirc \triangle \square$ 工業

産業医 $\square \square \quad \square \square$

\begin{tabular}{|l|l|}
\hline 氏名 & $\triangle \triangle \triangle \triangle(40$ 歳 男性 $)$ \\
\hline 確認事項 & 現在の精神状態をどうとらえるかについて \\
\hline
\end{tabular}

いつも大変お世話になっております。上記従業員に対し、御加療いただきありがと うございます。

弊社社員 $\triangle \triangle \triangle \triangle$ は、残業禁止の就業制限をかけて復職しております。復職して

1 カ月がたち、就業制限の見直しを考えているところですが、就業制限を解除して問

題ないかどうかご高診の程、宜しくお願い致します。

添付資料 2 .

\section{診療情報提供依頼書 \\ パターン I -2}

○メンタルクリニック

$\bigcirc \bigcirc \bigcirc$ 院長先生 御机下

(株) $\bigcirc \triangle \square$ 工業

産業医 $\square \square \quad \square \square$

\begin{tabular}{|l|l|}
\hline 氏名 & $\triangle \triangle \triangle \triangle(40$ 歳 男性 $)$ \\
\hline 確認事項 & $\begin{array}{c}\text { 現在の精神状態をどうとらえるかについて } \\
\text { (就業配慮への助言のお願い })\end{array}$ \\
\hline
\end{tabular}

いつも大変お世話になっております。上記従業員に対し、御加療いただきありがと うございます。現在の精神状態をどうとらえるべきかご教示いただけると幸いです。

弊社社員 $\triangle \triangle \triangle \triangle$ $\triangle$ は、休職前、製造ラインに入っていたのですが、製造ラインは 新規立ち上げの部署で精神的負担が大きいこと、またもともと検査部が長かったこと から、慣れ親しんだ検査部で残業禁止という就業制限の下での復職となりました。

今回、復職 1 力月後面談にて状況を確認しましたところ、仕事は問題なくできてい るようなのですが、仕事がない時や待ち時間の時に「居ても立っても居られないよう な気分になる」と訴えています。また休日も趣味の釣りに行っているようですが、こ れも楽しみで行っているというより、家にいてじっとしているのが耐えられないから 釣りに行くようにしていると訴えています。

動けているということから考えますと意欲がわいてきたと捉えてよいのかと思うの ですが、「居ても立っても居られないような気分になる」という状態をどう捉えるべき なのか、動けているので残業禁止の就業制限を解除してよいのか、それともまだ症状 が残存していると捉え、就業制限をかけたままで様子を見守ったほうがよいのか迷う ところです。現在の精神状態をどうとらえ、就業配慮を行うべきかご助言いただけた らと思います。

ご多忙とは存じますが、よろしくお願い致します。 
添付資料 2 .

診療情報提供依頼書

パターン I -3

○○ンタルクリニック

$\bigcirc \bigcirc \bigcirc \bigcirc$ 院長先生 御机下

(株) $\bigcirc \triangle \square$ 工業

産業医 $\square \square \quad \square \square$

\begin{tabular}{|l|l|}
\hline 氏名 & $\triangle \triangle \triangle \triangle(40$ 歳 男性 $)$ \\
\hline 確認事項 & $\begin{array}{l}\text { 現在の精神状態をどうとらえるかについて } \\
\text { (就業配慮への助言のお願い })\end{array}$ \\
\end{tabular}

いつも大変お世話になっております。上記従業員に対し、御加療いただきありがと うございます。現在の精神状態をどうとらえるべきかご教示いただけると幸いです。

弊社社員 $\triangle \triangle \triangle \triangle$ は、休職前、製造ラインに入っていたのですが、製造ラインは 新規立ち上げの部署で精神的負担が大きいこと、またもともと検査部が長かったこと から、慣れ親しんだ検査部で残業禁止という就業制限の下での復職となりました。

今回、復職 1 力月後面談にて状況を確認しましたところ、仕事は問題なくできてい るようなのですが、仕事がない時や待ち時間の時に「居ても立っても居られないよう な気分になる」と訴えています。また休日も趣味の釣りに行っているようですが、こ れも楽しみで行っているというより、家にいてじっとしているのが耐えられないから 釣りに行くようにしていると訴えています。

家にいるのが嫌な理由の一つとして最近妻との仲が今一つということも理由に挙げ ています。

本人によりますと、先生から「無理のない範囲で体を動かすように」と指示を受け ているとのことです。ただ話を伺っておりますと、無理のない範囲でというより何か にせきたてられて動いているような気が致します。

動けているということから考えますと意欲がわいてきたと捉えてよいのかと思うの ですが、「居ても立っても居られないような気分になる」という状態をどう捉えるべき なのか、動けているので残業禁止の就業制限を解除してよいのか、それともまだ症状 が残存していると捉え、就業制限をかけたままで様子を見守ったほうがよいのか迷う ところです。現在の精神状態をどうとらえ、就業配慮を行うべきかご助言いただけた らと思います。

もともとまじめな方であり、上司からの信頼も厚い方です。私としましては焦って 元の状態に戻ってまた休職という状態を避けることが何もよりも重要と考えており、 この考えは直属上司とも一致しております。

今回、私が先生に上記の内容で意見書を求めることに関しては本人の同意を得てお り、また先生からご教示いただく内容に関して、必要があれば本人の同意を得られた 内容に関してのみ職場に提示していく予定です。

ご多忙とは存じますが、ご意見のほどよろしくお願い致します。 
添付資料 2 .

\section{診療情報提供依頼書 \\ パターン II -1}

○○メンタルクリニック

$\bigcirc \bigcirc \bigcirc$ 院長先生 御机下

（株） $\bigcirc \triangle \square$ 商会

産業医 $\square \square$ प

\begin{tabular}{|l|l|}
\hline 氏名 & $\triangle \triangle \triangle \triangle(40$ 歳 男性 $)$ \\
\hline 確認事項 & 貴科的ご高診 \\
\hline
\end{tabular}

この度はお世話になります。

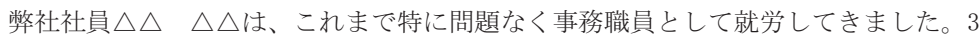
か月ほど前より、「これは私に対するあてつけだ」「みんな馬鹿にしている」などとぼ そぼそと語る行為を認めるようになったとのことです。

本日、職場にて「私を見て笑うのはやめてください」と向かいの席の職員に怒鳴る 行為を認めたとのことで、上司から相談を受けた次第です。

上記従業員に対し、貴科的ご高診の程、よろしくお願い致します。

添付資料 2 .

\section{診療情報提供依頼書 \\ パターン II -2}

○○ンタルクリニック

$\bigcirc \bigcirc \bigcirc$ 院長先生 御机下

（株） $\bigcirc \triangle \square$ 商会

産業医 $\quad \square \square \square \square$

\begin{tabular}{|l|l|}
\hline 氏名 & $\triangle \triangle \triangle \triangle(40$ 歳 男性 $)$ \\
\hline 確認事項 & 貴科的ご高診 \\
\hline
\end{tabular}

この度はお世話になります。

弊社社員 $\Delta \triangle \Delta \triangle$ 列、これまで特に問題なく事務職員として就労してきました。3 か月ほど前より、「これは私に対するあてつけだ」「みんな馬鹿にしている」などとぼ そぼそと語る行為を認めるようになったとのことです。

本日、職場にて「私を見て笑うのはやめてください」と向かいの席の職員に怒鳴る 行為を認めたとのことで、上司から産業医面談を勧められ、話を伺う運びとなりまし た。

話を伺っていますと、以前より嫌がらせを受けていると感じており、重要な書類が なくなったり、大切な会議の日程が自分だけ伝えられなかったりしていたとのことで す。本日、向かいの席の職員が自分のことを見てにやりと笑ったため、向かいの人が 悪だくみをしていたのだと確信したと訴えております。

上司によると職場において本人に対して嫌がらせをするような事実はないとのこと でした。もともと人付き合いのいいほうではなかったらしいのですが、ここ数カ月 特にピリピリしたような様子とのことでした。職場は $\triangle \triangle$ 氏の状態をどうとらえてよ いのか分からず、特に怒鳴られた向かいの人は、 $\triangle \Delta$ 氏にひどくおびえているとのこ とです。今の部署に異動してきて 4 年目であり、職場としては業務上過度なストレス というものは思い当たらないとのことです。

発言内容を周囲の情報と照らして合わせてもつじつまが合わず、妄想ととらえてよ いのかと考える次第ですが、診断、治療の必要性の有無、また職場として気を付ける 点をご教示いただけますと幸いです。

上記従業員に対し貴科的ご高診の程、よろしくお願い致します。 
添付資料 2 .

診療情報提供依頼書

パターン II -3

○メンタルクリニック

$\bigcirc \bigcirc \bigcirc$ 院長先生 御机下

(株） $\bigcirc \triangle \square$ 商会

産業医 $\square \square \quad \square \square$

\begin{tabular}{|l|l|}
\hline 氏名 & $\triangle \triangle \triangle \triangle(40$ 歳 男性 $)$ \\
\hline 確認事項 & 貴科的ご高診 \\
\hline
\end{tabular}

この度はお世話になります。上記従業員に対し貴科的ご高診の程、よろしくお願い 致します。

弊社社員 $\triangle \Delta \triangle \triangle$ $\triangle$ は、これまで特に問題なく事務職員として就労してきました。3 か月ほど前より、「これは私に対するあてつけだ」「みんな馬鹿にしている」などとぼ そぼそと語る行為を認めるようになったとのことです。

本日、職場にて「私を見て笑うのはやめてください」と向かいの席の職員に怒鳴る 行為を認めたとのことで、上司から産業医面談を勧められ、話を伺う運びとなりまし た。

話を伺っていますと、以前より嫌がらせを受けていると感じており、重要な書類が なくなったり、大切な会議の日程が自分だけ伝えられなかったりしていたとのことで す。本日、向かいの席の職員が自分のことを見てにやりと笑ったため、向かいの人が 悪だくみをしていたのだと確信したと訴えております。

上司によると職場において本人に対して嫌がらせをするような事実はないとのこと でした。もともと人付き合いのいいほうではなかったらしいのですが、ここ数力月 特にピリピリしたような様子とのことでした。職場は $\Delta \triangle$ 氏の状態をどうとらえてよ いのか分からず、特に怒鳴られた向かいの人は、 $\triangle \triangle$ 氏にひどくおびえているとのこ とです。

今の部署に異動してきて 4 年目であり、職場としては業務上過度なストレスという ものは思い当たらないとのことです。発言内容を周囲の情報と照らして合わせてもつ じつまが合わず、妄想ととらえてよいのかと考える次第ですが、診断、治療の必要性 の有無、また職場として気を付ける点をご教示いただけますと幸いです。

職場が不安がっていますので、先生の意見書から $\triangle \triangle$ 氏の状態をとらえた上で、本 人から同意を得て、必要最低限の情報を職場にフィードバックし、 $\triangle \triangle$ 氏の職場での 精神的安定をはかるとともに同時に職場全体も安定させたいと考えています。

今回、主治医の先生に $\triangle \triangle$ 氏から聞いた情報を伝え、診断の必要性があるのかどう か確認するという点に関しては本人の同意を得ています。しかし状態像として妄想を 疑っているということは伝えていません。仮に先生の御診断が統合失調症や妄想性障 害であった場合、病名まで告知したのかどうか、 $\triangle \triangle$ 氏の状態を先生からはどのよう にご説明されたのかまでご教示いただければ、今後の情報の伝え方に留意し、 $\triangle \triangle$ 氏 が職場内で不利な状態に置かれないよう対応いたします。また、職場への情報提供は 治療的支援となる最低限の情報提示のみ、本人同意のもと行いたいと考えています。

ご多忙とは存じますが、上記従業員に対し貴科的ご高診の程、よろしくお願い致し ます。 


\title{
Examination of factors for promoting cooperation using documents between occupational health physicians and psychiatrists
}

\author{
Makoto Okawara ${ }^{1}$, Shigeyuki KajIKI ${ }^{2}$, Akira Kusumoto ${ }^{3}$, Yoshihisa Fujino ${ }^{4}$, Takahiro Shinkai ${ }^{5}$, Hideki Morimoto ${ }^{1.6}$, \\ Yoshiyuki $\mathrm{Hino}^{7}$, Satoshi Yamashita ${ }^{1}$, Michihiro HatToRI ${ }^{8}$ and Koji MorI ${ }^{2}$
}

\author{
${ }^{1}$ Occupational Health Training Center, University of Occupational and Environmental Health, Japan \\ ${ }^{2}$ Department of Occupational Health Practice and Management, Institute of Industrial Ecological Sciences, University of Occupa- \\ tional and Environmental Health, Japan \\ ${ }^{3}$ RICOH San-Ai Group Health Promotion Group, Japan \\ ${ }^{4}$ Department of Preventive Medicine and Community Health, University of Occupational and Environmental Health, Japan \\ ${ }^{5}$ Department of Psychiatry, University of Occupational and Environmental Health, Japan \\ ${ }^{6}$ Morimoto Occupational Health Physician Office, Japan \\ ${ }^{7}$ HINO Occupational Health Consultant Office, Japan \\ ${ }^{8}$ Nishinihon Occupational Health Service Center, Japan
}

\begin{abstract}
Objectives: There is little specific information concerning the method and the efficacy of sharing information between occupational health physicians and psychiatrists regarding the employment status and medical history of their patients with mental illnesses. To promote cooperation between occupational health physicians and psychiatrists, we examined the points necessary to be included on medical information request forms exchanged between them. Methods: We conducted focused group discussion (FGD) to identify the points that need to be described on the request form and the concerns in cooperation between occupational health physicians and psychiatrists. We conducted FGDs twice, with two different groups of nine psychiatrists participating in each round. We extracted and organized FGD results and determined the necessary request form points. Next, we assumed two different cases of workers with mental illnesses and created three request form templates with differing item descriptions and lengths. We also conducted a questionnaire survey among clinical psychiatrists to determine their impression of the templates. We performed logistic regression analysis on the obtained results. Results: On the basis of the FGD results we extracted the situation in the workplace, clarification of points to be confirmed, representation of the occupational health physician's position, and handling of information provided by the doctor as points required for the request form. On the basis of these results and the opinions of occupational health specialists, we created a new request form using these points. Additionally, the results from the questionnaire survey about the prescribed items revealed the proportion of favorable answers regarding sufficient information written on the request form and a feeling of security for information provision increased $(p<0.01)$. Conversely, the proportion of favorable responses for readability decreased. Conclusions: Psychiatrists are concerned about the possibility that their patient may be at a disadvantageous situation by providing their personal medical information and believe the clinical information required by the occupational health physicians is unclear. This suggests that there are factors impeding the cooperation between the occupational health physicians and psychiatrists. When an occupational health physician writes a request form, cooperation with psychiatrists may be promoted by enriching the request form contents and by including the representation of the occupational health physician's position and the intended purpose of the provided information by paying attention to the volume of sentences.
\end{abstract}

(Sangyo Eiseigaku Zasshi 2018; 60: 1-14) 